\title{
Sterilization and quality variation of dried red pepper by atmospheric pressure dielectric barrier discharge plasma
}

\author{
Yoon Seok Song ${ }^{1}$, Yu Ri Park ${ }^{1}$, Seung Min Ryu ${ }^{2}$, Hyeong Won Jeon ${ }^{2}$, \\ Sang Heum Eom ${ }^{2}$, Seung Je Lee ${ }^{1 *}$ \\ ${ }^{1}$ Research and Development Office, Jeonbuk Institute for Food-Bioindustry, Jeonju 54810, Korea \\ ${ }^{2}$ Innovation Technology Research Division, Plasma Technology Research Center, National Fusion Research Institute, \\ Gunsan 54004, Korea
}

\section{대기압 유전체장벽방전 플라즈마에 의한 건고추의 식중독균 살균효과 및 품질변화}

\author{
송윤석 ${ }^{1} \cdot$ 박유리 $^{1} \cdot$ 유승민 $^{2} \cdot$ 전형원 $^{2} \cdot$ 엄상흠 $^{2} \cdot$ 이승제 $^{1 *}$ \\ ${ }^{1}$ 전라북도생물산업진흥원, ${ }^{2}$ 국가핵융합연구소 플라즈마기술연구센터
}

\begin{abstract}
This study was conducted to explore the potential for use of atmospheric pressure dielectric barrier discharge plasma (atmospheric pressure DBD plasma) as a non-thermal sterilization technology for microorganisms in dried red pepper. The effects of key parameters such as power, exposure time and distance on the sterilization efficiency and the quality of red dried pepper by the atmospheric pressure DBD plasma treatment were investigated. The results revealed that the plasma treatment was very effective for sterilization of Staphylococcus aureus, with 15 min of treatment at $1.0 \mathrm{~kW}$ and $20 \mathrm{~mm}$ sterilizing $82.6 \%$ of the $S$. aureus. Increasing the power or exposure time and decreasing the exposure distance led to improved sterilization efficiency. The atmospheric pressure DBD plasma treatment showed no effect on the ASTA (American spice trade association) value or hardness of dried red pepper. Furthermore, no effects of atmospheric pressure DBD plasma treatment were observed on the sensory properties of dried red pepper. To assess the storage stability, the dried red pepper was treated with atmospheric pressure DBD plasma (1.5 kW power, $15 \mathrm{~min}$ exposure time and $10 \mathrm{~mm}$ exposure distance), then stored for 12 weeks at $25^{\circ} \mathrm{C}$. Consequently, the ASTA value, hardness and capsaicin concentration of dried red pepper were maintained.
\end{abstract}

Key words : atmospheric pressure dielectric barrier discharge plasma, dried red pepper, Staphylococcus aureus, sterilization, storage

\section{서 론}

현대인들은 식품의 위생 및 품질에 민감하여 신선한 품 질을 그대로 유지하면서 장기적으로 보존이 가능한 식품을 원하고, 건강에 대한 관심과 사회 전반적인 웰빙 경향

*Corresponding author. E-mail : sjlee@jif.re.kr

Phone : 82-63-210-6541, Fax : 82-63-210-6529

Received 21 November 2016; Revised 20 December 2016; Accepted 23 December 2016.

Copyright (c) The Korean Society of Food Preservation. All rights reserved. (well-being trend)에 따라 농산물과 같은 자연식품을 선호 한다(1). 그러나 농산물은 종자, 재배, 수확 후 저장 과정에 서 유해미생물에 오염될 수 있기 때문에 식중독 발생 가능 성이 높은 식품이다(2).

농산물의 살균방법은 비약제(non-chemical) 및 비가열 (non-thermal)의 특징을 지닌 기술이 요구되어진다. 그 이유 로써 약제에 의한 살균은 인체 유해물질 및 오염물질이 발생되고(3), 가열살균은 각 농산물이 가지고 있는 천연의 풍미 및 조직감을 잃거나, 영양소 파괴 및 변색이 발생하기 때문이다(4). 현재 농산물 살균을 위해 가장 적극적으로 사용되고 있는 적외선 및 자외선 방법은 제품의 품질변화가 
적고, 환경 및 영양학적 문제도 없으나 살균효과가 낮은 단점이 있다(5).

최근 농·식품의 비가열 살균기술로서 플라즈마기술에 관심이 모아지고 있다(6). 플라즈마는 기체가 보다 높은 에너지를 가지게 되었을 때, 이온과 전자로 분리되면서 이 들이 갖는 에너지가 서로 평행을 이루는 상태를 의미하고 (7), 하전입자뿐만 아니라 화학적 반응성이 큰 활성 라디칼, 자외선 및 적외선 등이 포함되어 물리·화학적 처리가 동시 에 가능하며, 저온에서 운전 가능한 미생물 살균기술로 주 목받고 있다(8). 그 중, 대기압 상에서 플라즈마를 발생시킬 수 있는 대기압 플라즈마기술이 식품 및 바이오 분야 적용 을 위해 활발한 연구가 진행되고 있다(7).

식품 분야에서 대기압 플라즈마는 대부분 식중독균과 잠재적 유해미생물을 대상으로 한 사멸효율 조사에 대한 연구가 보고되고 있다. Youn과 $\operatorname{Mok}(9)$ 은 3 7분의 대기압 플라즈마 처리에 의해 백미, 현미, 압맥 표면에 존재하는 일반세균의 $90 \%$ 가 사멸되었고, 대기압 플라즈마는 백미, 현미, 압맥의 품질에 영향을 미치지 않았다고 보고하였으 며, Lee 등(10)은 대기압 플라즈마 10 분 처리에 의해 훈제연 어에 접종된 식중독균인 Listeria monocytogenes의 $90 \%$ 가 사멸되었음을 보고하였다. 다른 한편, 의생명 분야에서는 암치료(11), 상처치유(12), 의치 레진 살균(13), 치아미백 (14) 등의 연구에 대기압 플라즈마가 활용되고 있다.

저온 플라즈마기술은 대기압 플라즈마와 감압 플라즈마 로 구분된다. 감압 플라즈마는 플라즈마 발생속도의 제어 가 용이하고, 균일한 플라즈마 생성이 가능한 장점이 있으 나, 진공에 가까운 상태까지 압력을 낮추는 설비가 필요하 고, 연속식 처리가 어려운 단점이 있다(15). 이에 반해, 대기 압 플라즈마는 대기압 하에서 플라즈마 생성이 일어나기 때문에 장비가 간단하고, 연속처리가 가능하며, 장치비가 낮은 장점으로 인해 대기압 플라즈마가 농·식품산업에 적 용 가능성이 높다. 대기압 플라즈마의 방전 형태는 유전체 장벽방전(DBD, dielectric barrier discharge), 코로나방전 (corona discharge), 마이크로웨이브방전(microwave discharge), 아크방전(arc discharge) 등이 있다. 이 중 유전체장벽방전은 매우 큰 비평형 조건에서 동작하고, 고출력 방전이 가능하 며, 전기적 충격이 없고, 넓은 면적을 처리할 수 있기 때문에 농·식품 처리에 적합한 방전 형태이다 $(7,8)$

본 연구에서는 넓은 면적을 처리할 수 있는 유전체장벽 형태의 대기압 플라즈마 처리에 따른 Staphylococcus aureus 의 살균효과와 건고추의 품질특성 변화 및 저장안정성에 미치는 영향을 조사하였다.

\section{재료 및 방법}

\section{실험재료}

본 연구에서 사용한 건고추는 2016년 농가(Sunchang,
Korea)에서 재배하여 건조한 분쇄가공 전 건고추를 사용하 였다.

\section{건고추로부터 미생물 분리 및 동정}

건고추에 존재하는 미생물의 분리를 위해 건고추 $25 \mathrm{~g}$ 은 멸균된 filter bag(Cole-Parmer, Vernon hills, IL, USA)에 투 입되었고, 멸균수 $225 \mathrm{~mL}$ 를 첨가한 뒤, 스토마커로 3 분간 $230 \mathrm{rpm}$ 으로 처리하였다. 그 후, 여액은 적절한 희석배수로 희석되었고, plate count agar(PCA, Difco, Sparks, MD, USA) 배지와 potato dextrose agar(PDA, Difco, Sparks, MD, USA) 배지에 도말하여 각각 48 시간 또는 72 시간 동안의 배양에 의해 각각의 단일 colony를 분리하였다. 분리된 colony는 마크로젠(Seoul, Korea)에 의뢰하여 세균은 $16 \mathrm{~S} \mathrm{rRNA}$, 곰팡 이는 ITS 5.8S rRNA sequencing을 통해 각각의 미생물을 동정하였다.

\section{Staphylococcus aureus 증균 및 시료 준비}

S. aureus 의 colony는 plate count broth(PCB, Difco, Sparks, $\mathrm{MD}, \mathrm{USA}$ )배지에 접종되었고, $37^{\circ} \mathrm{C}$ 에서 48 시간 동안 배양 하였으며, 이 배양액을 12-well plate(Corning Incorporated, Kennebunk, ME, USA)에 분주하여 대기압 유전체장벽방전 플라즈마(atmospheric pressure DBD plasma)의 미생물 사멸 효과를 평가하기 위한 미생물 시료로 사용하였다.

\section{대기압 유전체장벽방전 플라즈마 장비 및 처리조건}

Fig. 1은 본 연구에서 사용한 유전체장벽방전 플라즈마 발생시스템 $(900 \mathrm{~mm}(\mathrm{H}) \times 400 \mathrm{~mm}(\mathrm{~W}) \times 650 \mathrm{~mm}(\mathrm{D}))$ 의 모식 도(Fig. 1A), 전체 외관(Fig. 1B), 플라즈마 발생 모듈(Fig. 1C)을 나타낸다. 플라즈마 발생 모듈 $(95 \mathrm{~mm}(\mathrm{H}) \times 118$ $\mathrm{mm}(\mathrm{W}) \times 364 \mathrm{~mm}(\mathrm{D}))$ 은 외부 housing과 플라즈마를 발생시 키는 metal 전극, metal 전극을 감싸고 있는 유전체, 가스를 고르게 분배시켜 주는 가스 distributor로 구성되었다. 세부 적으로, 외부 housing은 anodized aluminum으로 제작되었 고, 전력이 인가되는 전력선과 가스, 그리고 수냉을 위한 냉각 포트가 top cover에 위치하도록 설계하였다. 플라즈마 발생을 위한 metal 전극은 aluminum bar로 구성되었고, 이 를 유전체로 감싸주어 아크를 방지하도록 하였으며, 유전 체는 세라믹을 사용하였다. 전극 내부는 냉각수에 의해 전 극이 가열되는 것을 방지하도록 하였으며, 가스는 모듈의 중앙으로 인입되고, 가스 distributor에 의해 전극에 고루 분사되어 전극의 전 영역에서 균일한 플라즈마가 발생되도 록 설계하였다. 플라즈마 처리는 전력 $(0.5 \sim 1.5 \mathrm{~kW})$, 노출시 간(1 15 min), 노출거리(5 35 mm)의 다양한 범위에서 수행 하였고, 이때 사용된 가스는 질소-산소 혼합가스(질소:산소 =99:1(v:v))를 사용하였으며, 흐름속도는 $200 \mathrm{~L} / \mathrm{min}$ 이었다. 

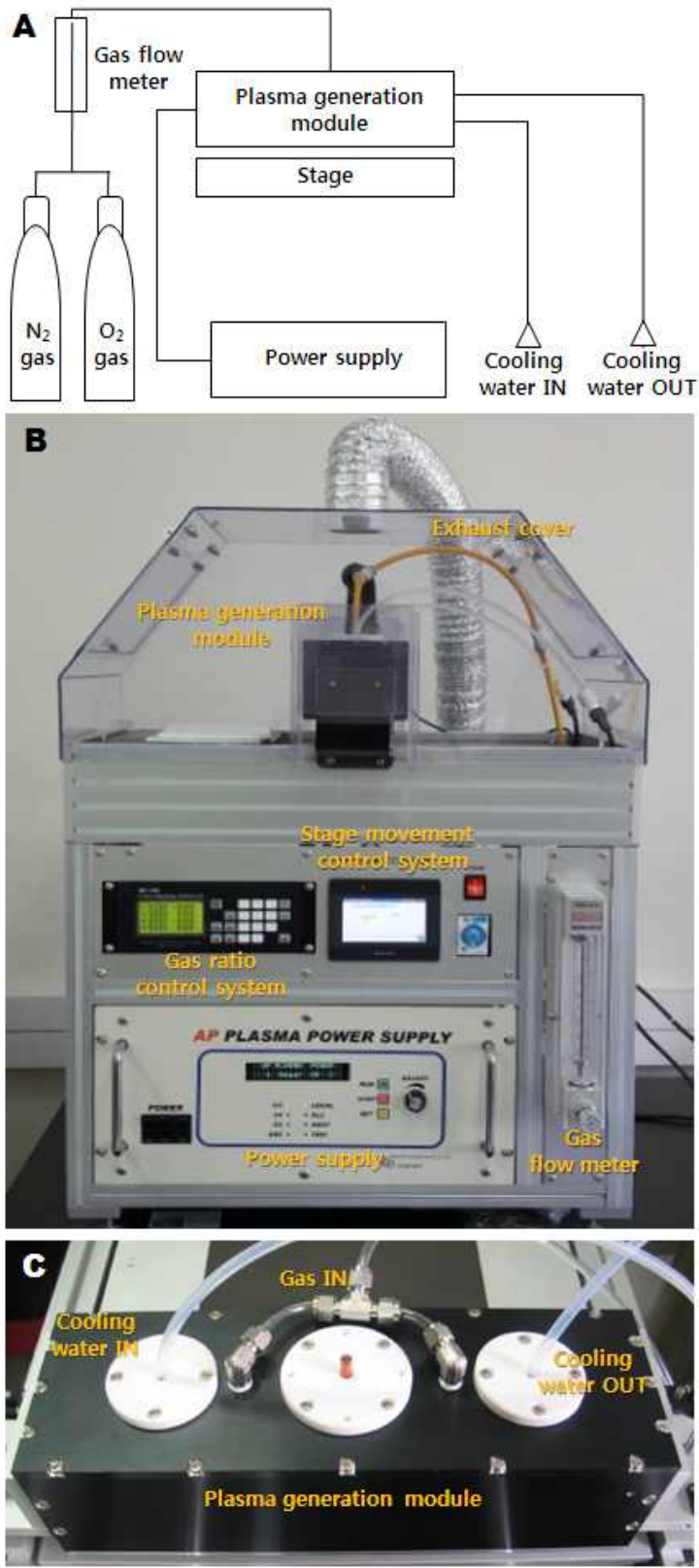

Fig. 1. Schematic diagram (A), overview (B) and plasma generation module (C) of atmospheric pressure DBD plasma generation system used in this study.

\section{Staphylococcus aureus 농도 분석}

플라즈마 처리 전·후 S. aureus의 농도는 미생물 시료를 희석하여 PCA 배지에 도말하고 $37^{\circ} \mathrm{C}$ 에서 48 시간 동안 배양 한 뒤 colony 수를 측정하여 $\mathrm{CFU} / \mathrm{mL}$ 로 표시하였다. 사멸율 은 플라즈마 처리 전 미생물 농도 $\left(\mathrm{N}_{0}\right)$ 와 플라즈마 처리 후 미생물 농도 $\left(\mathrm{N}_{t}\right)$ 를 측정한 뒤, 아래의 식에 대입하여 계산하 였다.

\section{건고추의 ASTA(American spice trade association)} value 분석

ASTA value는 씨가 제거된 건고추를 분쇄한 분말시료 $0.1 \mathrm{~g}$ 을 acetone(Sigma-Aldrich, St. Louis, MO, USA) 100 $\mathrm{mL}$ 에 첨가한 후, $25^{\circ} \mathrm{C}$ 암실에서 16 시간 동안 추출한 후, 추출액을 여과하여 $460 \mathrm{~nm}$ 에서 흡광도를 측정함으로써 분 석하였다.

\section{건고추의 경도 분석}

건고추의 경도는 texture analyzer(TA-XT2i, Stable Micro System Co, Surey, UK)를 사용하여 플라즈마 처리 전·후의 건고추를 30회 반복 측정하였다. Option은 return to start, pre-test speed는 $0.5 \mathrm{~mm} / \mathrm{sec}$, test speed는 $0.5 \mathrm{~mm} / \mathrm{sec}$, post-test speed는 $10 \mathrm{~mm} / \mathrm{sec}$, data acquisition rate는 $400 \mathrm{pps}$, target distance는 $1 \mathrm{~mm}$ 로 설정하였고, $2 \mathrm{~mm}$ diameter aluminum cylinder probe를 사용하여 건고추의 경도를 측정 하였다.

\section{건고추의 중량 감소율 분석}

건고추의 중량 감소율은 플라즈마 처리 전 건고추의 무 게(A)와 플라즈마 처리 후 건고추의 무게(B)를 측정한 뒤, 아래의 식에 대입하여 중량 감소율을 계산하였다.

$$
\text { Weight } \operatorname{loss}(\%)=\frac{\mathrm{A}-\mathrm{B}}{\mathrm{A}} \times 100
$$

\section{건고추의 capsaicin 농도 분석}

건고추를 분쇄한 분말시료 $0.5 \mathrm{~g}$ 은 acetonitrile(SigmaAldrich) $5 \mathrm{~mL}$ 에 투입되었고, $80^{\circ} \mathrm{C}$ 에서 4시간 추출하였다. 추출된 시료는 고성능 액체 크로마토그래피(High performance liquid chromatography, Agilent Technology, Agilent 1200, Santa Clara, CA, USA)를 이용하여 $\mathrm{C}_{18}$ column $(4.6 \times 250 \mathrm{~mm}$, $100 \stackrel{\mathrm{A}}{ }, 5 \mu \mathrm{m}$, Waters, Milford, MA, USA), 이동상 73\%(v/v) methanol, $0.6 \mathrm{~mL} / \mathrm{min}$ 유속으로 $\mathrm{UV}$ 검출기의 $284 \mathrm{~nm}$ 파장 에서 분석하였고, capsaicin 표준품은 Sigma-Aldrich사의 제 품을 사용하였다.

\section{건고추의 관능평가}

플라즈마 처리 전·후 건고추의 관능평가는 20 40대 20명 을 대상으로 건고추를 분쇄하여 물에 분산시켜 섭취하는 형태로 실시하였다. 관능평가를 위한 시료는 분쇄된 고춧 가루 $0.5 \mathrm{~g}$ 을 물 $50 \mathrm{~mL}$ 에 분산시킨 시료를 사용하였고, 평가항목은 색, 맛, 향 및 전체적 기호도로 설정하였으며, 5점 척도법을 사용하였다.

\section{건고추의 저장안정성 평가}

플라즈마 처리된 건고추의 저장안정성은 $25^{\circ} \mathrm{C}$ 에서 12 주 
간 수행되었다. 시료는 1 주 간격으로 채취되었고, 건고추의 ASTA value, 중량 감소율, 경도, capsaicin 농도 변화를 분석 하였다.

\section{통계처리}

통계처리는 SPSS(statistical package social science) 12.0 을 이용하여 분석하였고, 각 실험군 간의 유의차 검증은 다중범위검정법(Duncan's multiple range test)를 실시하여 $\mathrm{p}<0.05$ 수준에서 검정하였다.

\section{결과 및 고찰}

\section{건고추 오염미생물 동정}

본 연구에서 사용한 건고추에 오염되어 있는 미생물은 세균 및 곰팡이로 구분하여 분리 후 동정하였다. 그 결과, 세균은 S. aureus, Bacillus amyloliquefaciens, Lactobacillus crispatus가 동정되었고, 곰팡이는 Irpex lacteus, Thermoascus crustaceus가 동정되었다. B. amyloliquefaciens는 주로 토양 에서 발견되는 섬유소, 전분, 단백질 분해능이 우수한 미생 물이고, I. lacteus는 식물의 셀룰로오스, 리그닌 등 난분해 성 물질의 분해능이 탁월하다고 보고되었으며, L. crispatus 와 T. crustaceus는 자연 환경에서 흔히 발견되는 미생물로 서 인체에 유해하지 않은 미생물들이다 $(16,17)$. 그러나 $S$. aureus는 식중독을 일으키는 병원성 미생물이기 때문에 그 위험성으로 인해 본 연구에서 사멸을 위한 대상 미생물로 선정하였다(18).

\section{대기압 유전체장벽방전 플라즈마 처리에 의한 미생물 사멸}

이온화 가스상태인 플라즈마에는 전자, 양이온, 음이온, 자유 라디칼, 자외선 광자 등을 포함한 활성종(reactive species)이 존재하고, 이 활성종은 미생물 세포막을 통해 확산되면서 세포막의 지질과 단백질, 그리고 세포 내의 $\mathrm{DNA}$ 와 같은 거대 분자들과 반응하여 세포를 손상시키는 것으로 보고되었다 $(19,20)$. 따라서, 플라즈마 처리를 위한 전력, 노출시간, 노출거리의 변화는 활성종 생성 및 농도에 영향을 미치기 때문에 이에 따른 $S$. aureus의 사멸효과를 조사하였다.

플라즈마 처리를 위한 기본조건은 전력 $1.0 \mathrm{~kW}$, 노출시 간 $5 \mathrm{~min}$, 노출거리 $20 \mathrm{~mm}$ 로 설정하였고, 미생물 시료는 S. aureus 농도가 $7.4 \log \mathrm{CFU} / \mathrm{mL}$ 인 시료를 사용하였다. 첫 번째로 플라즈마 처리조건이 노출시간 $5 \mathrm{~min}$, 노출거리 $20 \mathrm{~mm}$ 일 때, 전력 $(0.5 \sim 1.5 \mathrm{~kW})$ 의 변화에 따른 사멸율을 조사하였다. 전력의 증가에 따라 $S$. aureus의 사멸율이 증가 하여 $1.5 \mathrm{~kW}$ 일 때, $66.6 \%$ 의 사멸율을 나타내었다(Fig. 2A). 이 결과는 전력의 증가에 따라 기체의 이온화, 여기, 해리 등의 과정이 더욱 빈번히 일어나기 때문에 활성종의 농도가 증가한 결과로 판단된다(21). 두 번째로 전력 $1.0 \mathrm{~kW}$, 노출
거리 $20 \mathrm{~mm}$ 일 때, 노출시간(1 15 $\mathrm{min})$ 의 변화에 따른 $S$. aureus의 사멸율을 조사한 결과, 노출시간의 증가에 비례하 여 사멸율이 증가하였고, 플라즈마에 $15 \mathrm{~min}$ 노출시켰을 때, S. aureus의 $82.6 \%$ 가 사멸하였다(Fig. 2B). 플라즈마에 노출되는 시간이 증가하게 되면 활성종의 농도와 자외선 세기 등이 일정하더라도 미생물의 세포막 손상 정도는 증가 하기 때문에 그로 인해 사멸율이 증가하는 결과를 나타낸다 (21). 세 번째로 플라즈마 처리조건이 전력 $1.0 \mathrm{~kW}$, 노출시 간 $5 \mathrm{~min}$ 일 때, 노출거리 $(10 \sim 35 \mathrm{~mm})$ 의 변화에 따른 $S$. aureus의 사멸율을 조사하였다. 그 결과, 노출거리의 증가 에 반비례하여 S. aureus의 사멸율이 감소하였고, 플라즈마 발생원과 미생물 시료의 거리가 $10 \mathrm{~mm}$ 일 때, $71.4 \%$ 의 사멸 율을 나타내었다(Fig. 2C). Ryu 등(7)은 대기압 유전체장벽 방전 플라즈마 처리에서 전력, 노출시간이 증가될수록 그 리고 노출거리가 짧을수록 활성종인 오존 $\left(\mathrm{O}_{3}\right)$, 일산화질소 (NO), 이산화질소 $\left(\mathrm{NO}_{2}\right)$ 등의 농도가 증가된다고 보고하였 고, 플라즈마 처리 시 전력과 노출시간이 증가할수록 Salmonella typhimurium, Escherichia coli의 사멸효과가 증 가된 것을 보고하였다 $(10,21,22)$. 또한, Mok과 Lee(23)는
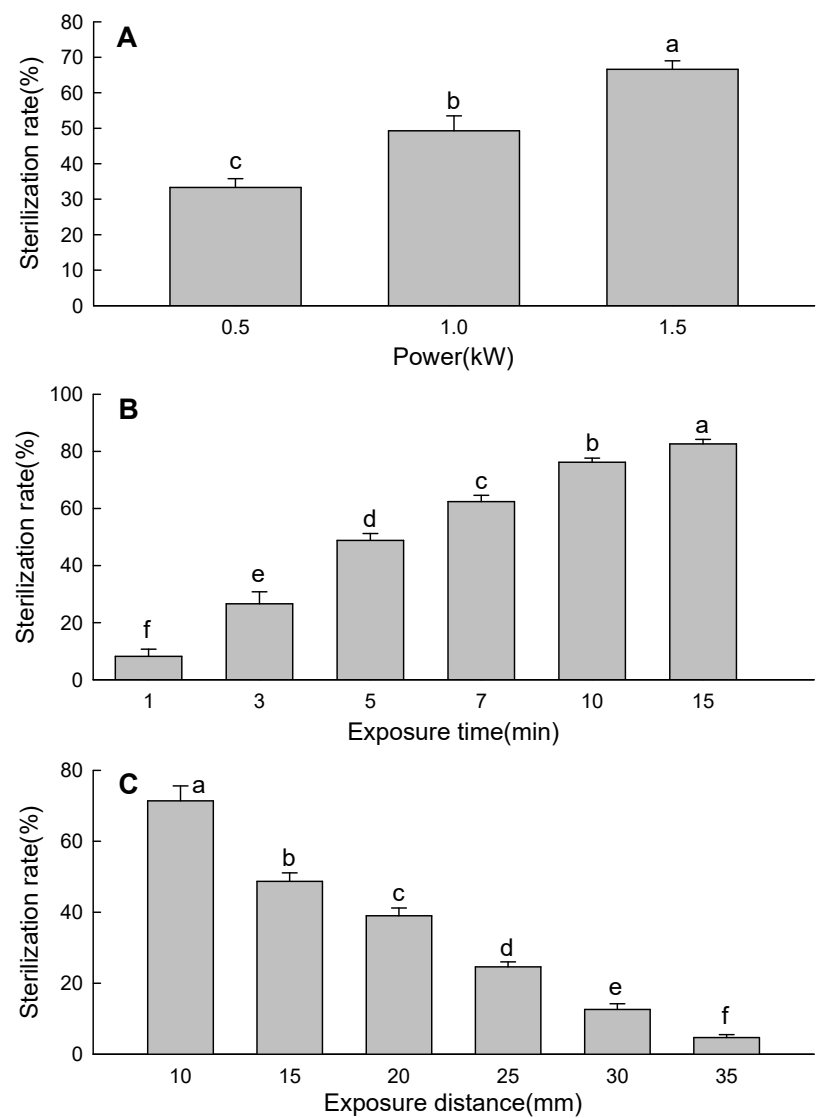

Fig. 2. Effects of power (A), exposure time (B) and distance (C) on $S$. aureus sterilization by atmospheric pressure DBD plasma treatment.

Values are means \pm SD $(n=3)$.

${ }^{a-f}$ Values are significantly different among the samples $(\mathrm{p}<0.05)$. 
전력의 증가에 의해 전류세기가 증가되고, 그로 인해 에너 지 투입속도가 증가하여 미생물의 사멸율이 증가한다고 보고하였다. 이러한 결과들로 미루어, 대기압 유전체장벽 방전 플라즈마 처리를 위해 인가되는 전력과 플라즈마 상태 에 노출되는 시간 및 플라즈마 발생원과 시료의 거리는 발생하는 활성종의 농도와 직접적인 관계가 있기 때문에 미생물 사멸에 큰 영향을 미친다.

\section{대기압 유전체장벽방전 플라즈마 처리에 따른 건고추의 특성 변화}

S. aureus 사멸을 위해 연구된 플라즈마 처리조건 하에 건고추가 노출되었을 때, 건고추의 특성에 미치는 영향을 조사하기 위하여 플라즈마 미처리 대조구(control)와 비교 하였다. ASTA value는 고추의 붉은색 정도를 의미하고, 건고추 품질규격의 척도이며, 경도는 건고추의 수분함량과 관계가 있어 분쇄공정에 영향을 미치기 때문에 매우 중요한 건고추의 특성이다. 따라서, 플라즈마 처리를 위해 전력 $1.0 \mathrm{~kW}$, 노출시간 $5 \mathrm{~min}$, 노출거리 $20 \mathrm{~mm}$ 를 기본 조건으로 설정하고, 각 인자의 변화에 따른 건고추의 ASTA value와 경도의 변화를 조사하였다. Fig. 3과 Fig. 4는 건고추의
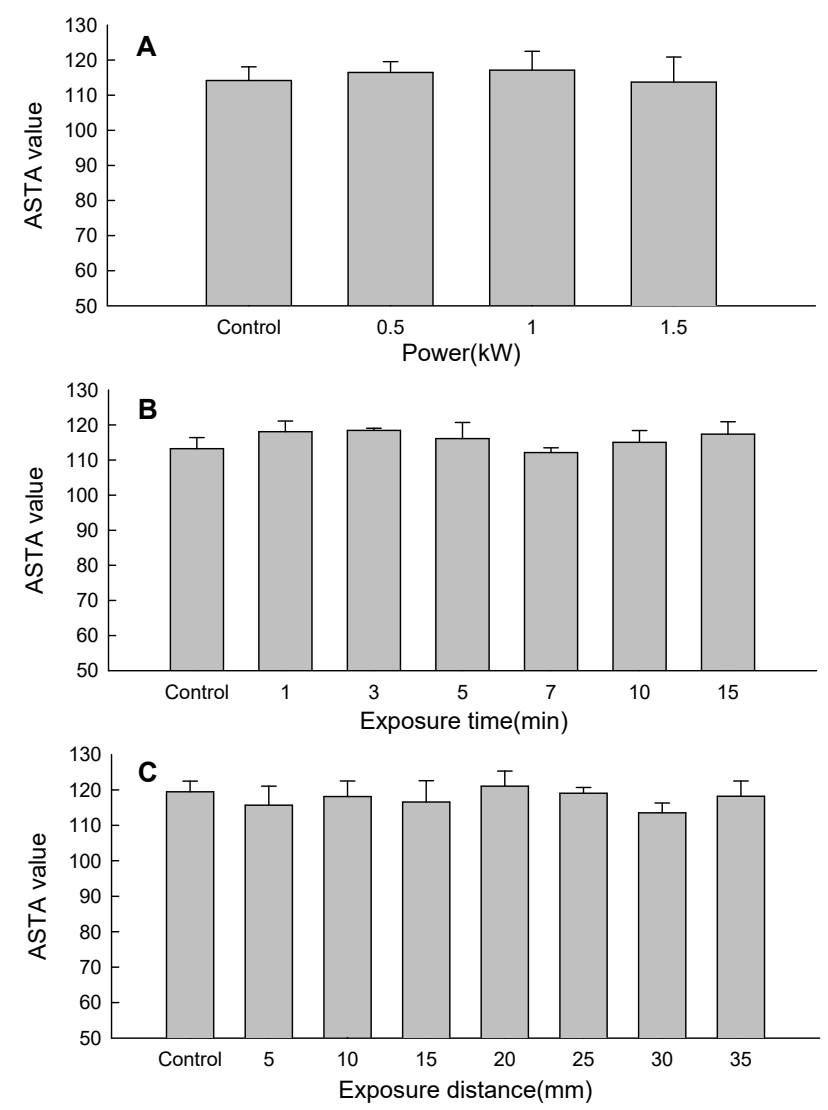

Fig. 3. Effects of power (A), exposure time (B) and distance (C) on ASTA value of dried red pepper treated by atmospheric pressure DBD plasma.

Values are means \pm SD $(n=3)$.
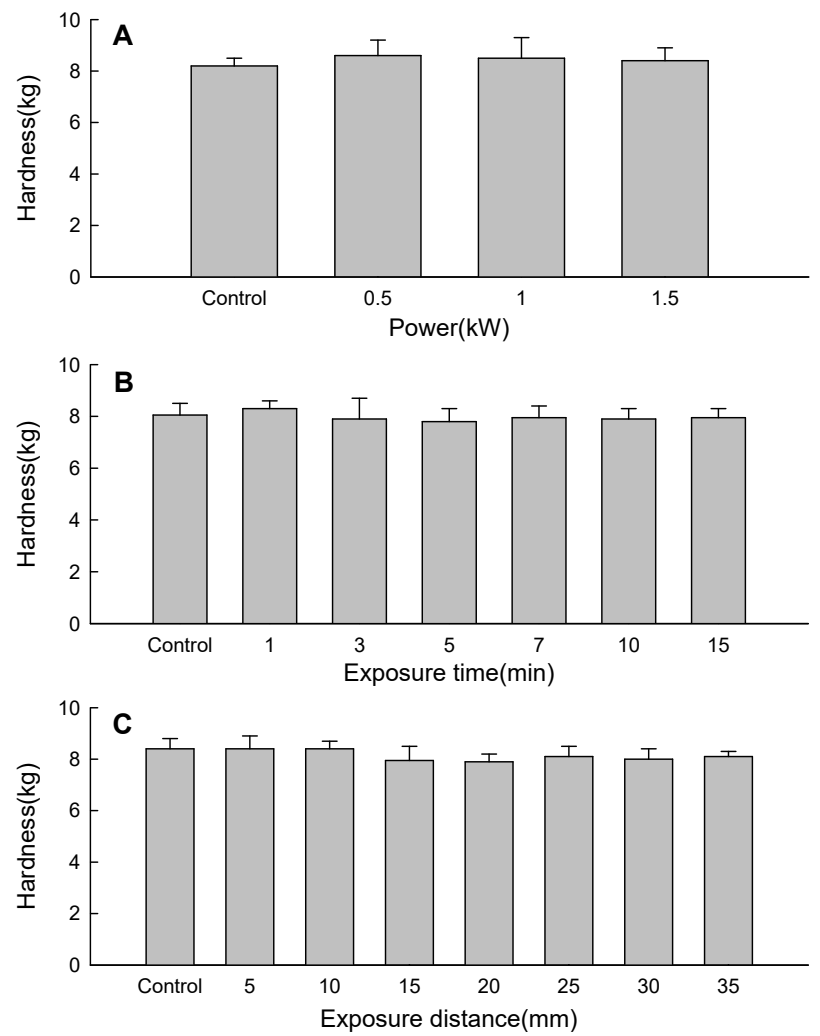

Fig. 4. Effects of power (A), exposure time (B) and distance (C) on hardness of dried red pepper treated by atmospheric pressure DBD plasma.

Values are means $\pm \mathrm{SD}(\mathrm{n}=30)$.

ASTA value와 경도의 변화를 보여준다. 전력, 노출시간, 노출거리의 변화는 각각의 대조구와 비교하여 건고추의 ASTA value 및 경도 변화에 영향을 미치지 않는 결과를 나타내었다. 더불어, 본 연구에서 수행한 가장 강한 플라즈 마 처리조건(전력 $1.5 \mathrm{~kW}$, 노출시간 $15 \mathrm{~min}$, 노출거리 10 $\mathrm{mm}$ )으로 건고추를 처리하였을 때, 건고추 표면의 온도가 초기 $25^{\circ} \mathrm{C}$ 에서 처리 종료 시 $45^{\circ} \mathrm{C}$ 까지 변화하는 결과로 미루어, 대기압 유전체장벽방전 플라즈마 처리에 의한 미 생물 사멸(Fig. 2)은 온도에 의한 영향이 아님을 증명하고, 온도에 민감한 농산물 처리에 큰 장점이 있음을 확인하였다 (data not shown).

\section{대기압 유전체장벽방전 플라즈마 처리에 따른 건고추의 관능특성 변화}

플라즈마 처리에 따른 건고추의 관능적 특성변화를 조사 하기 위하여 본 연구에서 수행한 가장 강한 플라즈마 처리 조건(전력 $1.5 \mathrm{~kW}$, 노출시간 $15 \mathrm{~min}$, 노출거리 $10 \mathrm{~mm}$ )으로 처리된 건고추와 플라즈마 미처리 건고추의 관능평가를 실시하였다. Table 1은 관능평가의 결과를 보여준다. 그 결과, 향, 맛, 색, 전체적 기호도는 $95 \%$ 신뢰도(p<0.05)에서 두 가지 건고추간 유의적 차이가 없는 것으로 나타났다. 
Table 1. Sensory properties of dried red pepper treated by atmospheric pressure DBD plasma

\begin{tabular}{ccc}
\hline Property & $\begin{array}{c}\text { Red pepper non-treated } \\
\text { by plasma }\end{array}$ & $\begin{array}{c}\text { Red pepper treated } \\
\text { by plasma }\end{array}$ \\
\hline Flavor & $3.93 \pm 1.08^{1) \mathrm{NS} 2)}$ & $4.23 \pm 1.14^{\mathrm{NS}}$ \\
Taste & $3.77 \pm 1.30^{\mathrm{NS}}$ & $3.43 \pm 1.01^{\mathrm{NS}}$ \\
Color & $3.73 \pm 1.11^{\mathrm{NS}}$ & $3.70 \pm 0.79^{\mathrm{NS}}$ \\
Overall acceptability & $3.87 \pm 1.20^{\mathrm{NS}}$ & $3.73 \pm 0.91^{\mathrm{NS}}$ \\
\hline
\end{tabular}

${ }^{1)}$ Mean \pm SD of 20 panelists. Means are not significantly different at $\mathrm{p}<0.05$.

${ }^{2)} \mathrm{NS}$, not significant.

따라서, 대기압 유전체장벽방전 플라즈마는 건고추의 관능 적 특성변화에 영향을 미치지 않는 것으로 판단된다. 이와 유사한 결과로 Mok과 Seon(24)은 감압방전 플라즈마를 처 리한 후춧가루의 관능특성이 미처리 후춧가루와 차이를 나타내지 않았다고 보고하였다. 이러한 결과들은 플라즈마 기술이 식품에서 매우 중요한 관능특성에 영향이 없는 유용 한 기술임을 보여준다.

\section{대기압 유전체장벽방전 플라즈마 처리 건고추의 저장안 정성 평가}

저장기간 중 플라즈마 처리 건고추의 특성변화를 조사하 기 위하여 플라즈마 처리 전 건고추를 대조구(0 week)로 하여 비교하였고, 전력 $1.5 \mathrm{~kW}$, 노출시간 $15 \mathrm{~min}$, 노출거리 $10 \mathrm{~mm}$ 조건에서 처리된 건고추를 $25^{\circ} \mathrm{C}$ 에서 12 주 동안 저장 하면서 중량 감소율, ASTA value, capsaicin 농도, 경도 변화 를 분석하였다. Fig. 5는 플라즈마 처리 건고추의 중량 감소 율, ASTA value, capsaicin 농도, 경도 변화를 보여준다. 12주 의 저장기간 동안 플라즈마 처리 건고추의 중량은 $1.47 \%$ 감소하였다. 이러한 결과는 저장기간 동안 건고추의 수분

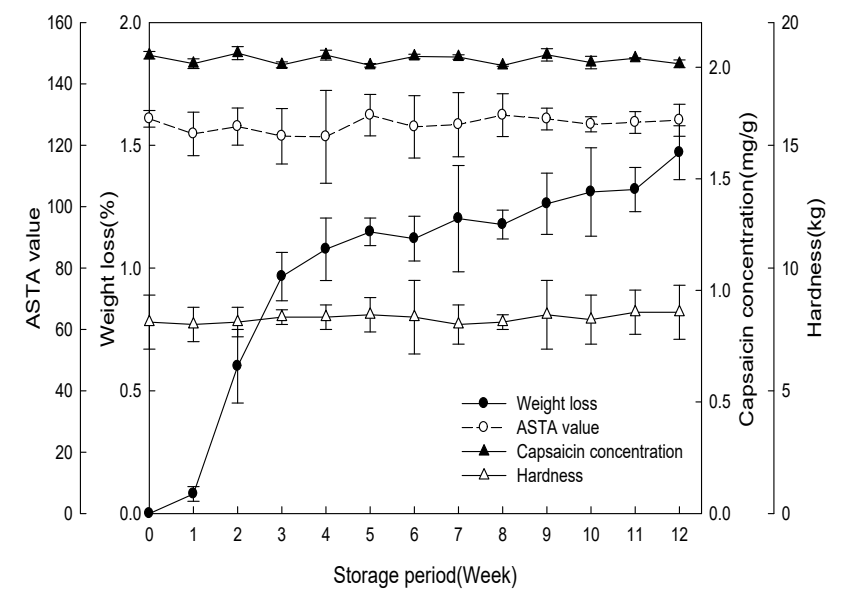

Fig. 5. Changes of weight loss, ASTA value, hardness and capsaicin concentration during storage of dried red pepper treated by atmospheric pressure DBD plasma.

Values of weight loss, ASTA value and capsaicin concentration are means \pm SD $(n=3)$. Values of hardness are means \pm SD $(n=30)$.
증발에 기인한 것으로 판단된다. 한편, 플라즈마 처리 건고 추의 ASTA value, capsaicin 농도, 경도는 12주의 저장기간 동안 일정하게 유지되어 대기압 유전체장벽방전 플라즈마 처리가 건고추의 저장성에 영향을 미치지 않음을 확인하 였다.

\section{요 약}

건고추에 존재하는 미생물은 세균 3종 $(S$. aureus, $B$. amyloliquefaciens, L. crispatus), 곰팡이 2종(I. lacteus, $T$. crustaceus)이 동정되었고, 그 중 인체 유해성이 있는 $S$. aureus를 대상으로 대기압 유전체장벽방전 플라즈마를 이 용한 미생물 사멸효과와 건고추의 품질변화에 미치는 영향 을 조사하였다. S. aureus의 사멸율은 플라즈마 처리를 위한 전력과 노출시간의 증가에 따라 증가하였고, 노출거리 증 가에 따라 사멸율이 감소하였다. 한편, 다양한 전력, 노출시 간, 노출거리 범위에서 건고추에 플라즈마를 처리한 결과, 건고추의 ASTA value 및 경도는 영향을 받지 않았고, 관능 특성(향, 맛, 색, 전체적 기호도)에서도 유의적 차이가 관찰 되지 않았다. 최종적으로, $25^{\circ} \mathrm{C}$ 에서 12 주 동안 플라즈마 처리된 건고추의 저장성을 평가한 결과, 건고추의 ASTA value, capsaicin 농도, 경도가 일정하게 유지됨으로 인해 대기압 유전체장벽방전 플라즈마기술이 농·식품산업에 적 용될 수 있는 유용한 살균기술임을 확인하였다.

\section{감사의 글}

이 논문은 2016년도 정부 출연 재원으로 국가핵융합연구 소 주요사업 중 '미래선도 플라즈마-농식품 선도기술 (Plasma Farming)개발'관련 사업에서 지원을 받아 수행된 연구임.

\section{References}

1. Lee KS, Park GS (2014) Studies in the consumption and preference for sprout vegetables. J East Asian Soc Dietary Life, 24, 896-905

2. Beuchat LR, Farber JM, Garrett EH, Harris LJ, Parish ME, Suslow TV, Busta FF (2001) Standardization of a method to determine the efficacy of sanitizers in inactivating human pathogenic microorganisms on raw fruits and vegetables. J Food Prot, 64, 1079-1084

3. Mahmoud BSM, Bhagat AR, Linton RH (2007) Inactivation kinetics of inoculated Escherichia coli 
O157:H7, Listeria monocytogenes and Salmonella enterica on strawberries by chlorin dioxide gas. Food Microbiol, 24, 736-744

4. Luksiene Z, Buchovec I, Paskeviciute E (2010) Inactivation of several strains of Listeria monocytogenes attached to the surface of packaging material by Na-Chlorophyllinbased photosensitization. J Photoch Photobio B, 101, 326-331

5. Song HP, Kim B, Choe JH, Jung S, Moon SY, Choe WH, Jo CR (2009) Evaluation of atmospheric pressure plasma to improve the safety of sliced cheese and ham inoculated by 3-strain cocktail Listeria monocytogenes. Food Microbiol, 26, 432-436

6. Laroussi M (2005) Low temperature plasma-based sterilization: overview and state-of-the-art. Plasma Processes Polym, 2, 391-400

7. Ryu YH, Uhm HS, Park GS, Choi EH (2013) Sterilization of Neurospora crassa by noncontacted low temperature atmospheric pressure surface discharged plasma with dielectric barrier structure. J Korean Vacuum Soc, 22, 55-65

8. Son HH, Lee WG (2011) Discharge properties of torch-type atmospheric pressure plasma and its local disinfection of microorganism. Korean Chem Eng Res, 49, 835-839

9. Yoon GA, Mok CK (2015) Microbial inactivation of grains used in Saengshik by corona discharge plasma jet. Korean J Food Sci Technol, 47, 70-74

10. Lee HB, Noh YE, Yang HJ, Min SC (2011) Inhibition of foodborne pathogens on polystyrene, sausage casings, and smoked salmon using nonthermal plasma treatments. Korean J Food Sci Technol, 43, 513-517

11. Fridman G, Friedman G, Gutsol A, Shekhter AB, Vasilets VN, Fridman A (2008) Applied plasma medicine. Plasma Processes Polym, 5, 503-533

12. De Geyter N, Morent R (2012) Nonthermal plasma sterilization of living and nonliving surfaces. Annu Rev Biomed Eng, 14, 255-274

13. Seo HY, Yoo EM, Choi YR, Kim SH, Kim KM, Kim $\mathrm{KN}$ (2014) Effect of non-thermal atmospheric pressure nitrogen and air plasma on the surface properties and the disinfection of denture base resin. J Korean Soc Dent Hyg, 14, 783-788

14. Kim JH, Lee MA, Han GJ, Cho BH (2014) Plasma in dentistry: a review of basic concepts and applications in dentistry. Acta Odontol Scand, 72, 1-12

15. Mok CK, Lee TH (2011) Operational properties and microbial inactivation performance of dielectric barrier discharge plasma treatment system. Food Eng Prog, 15, 398-403

16. Sim HS, Kim MD (2016) Antipathogenic activity of Bacillus amyloliquefaciens isolated from korean traditional rice wine. Micobiol Biotechnol Lett, 44, 98-105

17. Kim YJ, Song HG, Choi HT (2008) Degradation of bisphenol A and removal of its estrogenic activity by two laccase transformants of Irpex lacteus. Kor J Microbiol, 44, 199-202

18. Park HS, Bahk GJ, Park KH, Pak JY, Ryu K (2010) Predictive model for growth of Staphylococcus aureus in Suyuk Korean J Food Sci Ani Resour, 30, 487-494

19. Laroussi M, Leipold F (2004) Evaluation of the roles of reactive species, heat and UV radiation in the inactivation of bacterial cells by air plasmas at atmospheric pressure. Int J Mass Spectrom, 233, 81-86

20. Bogaerts A, Neyts E, Gijbels R, Mullen V (2002) Gas discharge plasmas and their application. Spectrochim Acta Part B, 57, 609-658

21. Jo JO, Lee HW, Mok YS (2014) Sterilization of scoria powder by corona discharge plasma. Appl Chem Eng, 25, 386-391

22. Kim JE, Kim IH, Min SC (2013) Microbial decontamination of vegetables and spices using cold plasma treatments. Korean J Food Sci Technol, 45, 735-741

23. Mok CK, Lee TH (2012) Dielectric barrier discharge plasma inactivation of Escherichia coli. Food Eng Prog, 16, 33-39

24. Mok CK, Jeon HJ (2013) Low pressure discharge plasma inactivation of microorganisms in black pepper powder. Food Eng Prog, 17, 43-47 